\title{
Effects of the amount and quality of dietary protein on nitrogen metabolism and heat production in growing pigs
}

\author{
By M. F. FULLER, A. CADENHEAD, G. MOLLISON AND B. SEVE* \\ Department of Applied Nutrition, Rowett Research Institute, Bucksburn, \\ Aberdeen $A B 2$ 9SB
}

(Received 4 April 1986 - Accepted 20 March 1987)

1. Eight pigs with a mean weight of $48 \mathrm{~kg}$ were given, at a constant daily rate, diets of low $(0 \cdot 15)$ or high $(0 \cdot 30)$ protein content, very deficient in lysine, with or without a supplement of L-lysine $(3.7 \mathrm{~g} / \mathrm{kg})$.

2. Measurements of nitrogen and energy metabolism were made in four successive $14 \mathrm{~d}$ periods in a Latinsquare design.

3. The rate of protein accretion was substantially increased by increases in both protein and lysine supply, but the rate of heat production was not significantly changed.

4. The rate of fat deposition varied inversely with the rate of protein accretion, being reduced by both protein and lysine supplements.

5. The relation between heat production and protein accretion (allowing for a constant energy cost of fat deposition) suggested that heat production increased with additional protein accretion less when protein quality was improved than when more protein was given.

It was Kielanowski (1965) who first proposed, and who later elaborated (Kielanowski, 1966) the idea that the energy requirement of a growing animal can be considered to be the sum of three components : the energy requirements for maintenance, protein accretion $(A)$ and fat deposition. Using multiple regression, he computed the association of metabolizable energy (ME) with $A$ and fat deposition. The residual quantity was assumed to be the energy required for maintenance. In recent years, experiments in several species have been made to estimate the magnitude of these specific costs. As far as growing pigs are concerned, a survey of experimental evidence (Fowler et al. 1980; Agricultural Research Council, 1981) suggested that the ME required for $A$ is, on average, $44 \mathrm{~kJ} / \mathrm{g}$ and for fat deposition $54 \mathrm{~kJ} / \mathrm{g}$. By subtracting from these values the heats of combustion of body protein and fat (23.7 and 39.6 kJ/g; Franke \& Weniger, 1958) the increases in heat production associated with protein and fat deposition are 20.3 and $14.4 \mathrm{~kJ} / \mathrm{g}$ respectively. These estimates are based on statistical associations, rather than physiological causation. It is simply to say that when the rate of $A$ is increased, energy expenditure increases in constant proportion: it is not to say that there is necessarily any direct causal link between the two.

By contrast, it has been estimated (Millward et al. 1976) that 4 mol ATP are required for each peptide bond formed and probably another $1 \mathrm{~mol}$ for additional associated energy expenditures in amino acid transport, RNA synthesis, etc. The synthesis of $5 \mathrm{~mol}$ ATP typically requires $400 \mathrm{~kJ} \mathrm{ME}$; assuming that the average molecular weight of amino acid residues is 116 , this suggests that $3.45 \mathrm{~kJ} \mathrm{ME}$ are expended for each $1 \mathrm{~g}$ protein synthesized. It might be thought that these estimates, $3.45 \mathrm{~kJ} / \mathrm{g}$ for protein synthesis $(S)$ and $20.3 \mathrm{~kJ} / \mathrm{g}$ for $A$, could be reconciled if protein turnover exceeded $A$ by a factor of 6 , which indeed it commonly does (Waterlow et al. 1978). However, what is important is not the overall ratio, $S: A$ but the marginal ratio, that is, the change in $S$ associated with a change in $A$. In a previous paper (Reeds et al. 1980) we showed that when nitrogen

\footnotetext{
- Present address: Station de recherches porcines, Saint-Gilles, 35590 L'hermitage, France.
} 
retention was increased by giving more food the relation between $S(\mathrm{~g} / \mathrm{d})$ and $A(\mathrm{~g} / \mathrm{d})$ in $35 \mathrm{~kg}$ pigs was described by the equation

$$
S=230+2 \cdot 2 A .
$$

The large intercept term reflects the fact that, even when there was no net accretion of protein, $230 \mathrm{~g}$ protein were synthesized daily. The energy expended in synthesizing this quantity of protein would be included in the maintenance term. The marginal ratio, $S: A$ was 2.2 and on this basis if the energy requirement for $S$ was the only determinant of the energy requirement for $A$, the increase in heat production $(H)$ associated with increased $A$ would be $2.2 \times 3.5$, i.e. $7 \cdot 7$ not $20.3 \mathrm{~kJ} / \mathrm{g}$.

In most of the studies so far made of this subject, increases in $A$ have been associated with increases in either protein or energy intake or both and it is possible that alterations of other components of metabolism induced by these changes may have been statistically associated with the observed changes in $A$. We now report the results of experiments in which $A$ was approximately doubled with virtually no change in energy or protein intake, by doubling the supply of the most limiting amino acid in the diet. It was not technically feasible to make all measurements on the same animals, so two experiments were made with two sets of similar animals. Measurements of $\mathrm{N}$ metabolism and $H$ were made in the first experiment, described in the present paper. Measurements of protein turnover are reported in the following paper (Fuller et al. 1987 b). A preliminary report of some of these results has been given (Fuller et al. 1987a).

\section{MATERIALS AND METHODS}

\section{Animals}

Eight female pigs, Large White $\times$ (Large White $\times$ Landrace) were used. They were selected when they weighed approximately $25 \mathrm{~kg}$ and were confined in metabolism cages during measurement periods and for $4 \mathrm{~d}$ beforehand. The room was maintained at $20^{\circ}$.

\section{Design}

The experiment was arranged as two $4 \times 4$ Latin squares, one running 1 week behind the other. Each period lasted for 2 weeks, during which the pig was given the appropriate diet. To allow adequate time for adaptation to the new diet, measurements were made in the 2 nd week of each period, so that measurements were being made on pigs in the two Latin squares in alternate weeks.

\section{Diets and feeding}

Four diets were used (Table 1). Diet 3 was the basic high-protein diet (HP) from which all the others were formed. It included a mixture of ingredients with lysine-deficient proteins, barley, sunflower-seed meal, sesame-seed meal and hydrolyzed feather meal. To form diet 1 (LP), diet 3 was diluted with a mixture of maize starch, sucrose, cellulose and maize oil, thus maintaining the same amino acid profile in each diet. Each of these diets was then supplemented with $4.7 \mathrm{~g} \mathrm{~L}$-lysine hydrochloride/ $\mathrm{kg}$ diet to give diets $2(\mathrm{LP}+)$ and $4(\mathrm{HP}+)$. One batch of each diet was used throughout. The diets were given in two daily meals at the rate of $120 \mathrm{~g} / \mathrm{kg}$ body-weight $(\mathrm{W})^{0.75}$ per $\mathrm{d}$, where $\mathrm{W}$ is the live weight the pigs were expected to reach at the middle of the period of measurement. 
Table 1. Composition of the diets

\begin{tabular}{|c|c|c|c|c|}
\hline Diet ... & $\begin{array}{c}1 \\
\text { (LP-) }\end{array}$ & $\begin{array}{c}2 \\
(L P+)\end{array}$ & $\begin{array}{c}3 \\
\text { (HP-) }\end{array}$ & $\begin{array}{c}4 \\
(\mathrm{HP}+)\end{array}$ \\
\hline \multicolumn{5}{|l|}{ Ingredients $(\mathrm{g} / \mathrm{kg})$} \\
\hline Ground barley & 248 & 248 & 496 & 496 \\
\hline Sesame-seed meal & 92 & 92 & 184 & 184 \\
\hline Sunflower-seed meal & 75 & 75 & 150 & 150 \\
\hline Hydrôlysed feather meal & 68.5 & $68 \cdot 5$ & 137 & 137 \\
\hline Maize starch & 410 & 410 & 0 & 0 \\
\hline Sucrose & 30 & 30 & 0 & 0 \\
\hline Cellulose & 25 & 25 & 0 & 0 \\
\hline Maize oil & 10 & 10 & 0 & 0 \\
\hline Dicalcium phosphate & 35 & 35 & 30 & 30 \\
\hline Sodium chloride & 3.8 & 3.8 & $3 \cdot 8$ & 3.8 \\
\hline Vitamins and minerals & $2 \cdot 6 \S$ & $2 \cdot 6 \S$ & $2 \cdot 5 \ddagger$ & $2 \cdot 5 \ddagger$ \\
\hline L-lysine hydrochloride & 0 & $4 \cdot 7$ & 0 & $4 \cdot 7^{\top}$ \\
\hline \multicolumn{5}{|l|}{$\begin{array}{l}\text { Analysis } \\
\text { A }\end{array}$} \\
\hline Dry matter $(\mathrm{g} / \mathrm{kg})$ & 888 & 887 & 889 & 889 \\
\hline Nitrogen $\times 6.25(\mathrm{~g} / \mathrm{kg})$ & 151 & 156 & 302 & 307 \\
\hline $\begin{array}{l}\text { Heat of combustion } \\
(\mathrm{kJ} / \mathrm{g} \mathrm{DM})\end{array}$ & $19 \cdot 10$ & - & $18 \cdot 77$ & - \\
\hline Total lysine ${ }^{\dagger}$ & 3.7 & 7.4 & 7.4 & $11 \cdot 1$ \\
\hline
\end{tabular}

DM, dry matter.

$\dagger$ Calculated from amino acid analyses of ingredients.

¥ Pigvite no. 2 (Norvite Ltd, Kennethmont, Aberdeenshire), supplying (/kg diet): retinol $3.64 \mathrm{mg}$, cholecalciferol $50 \mu \mathrm{g}, \alpha$-tocopherol $6.7 \mu \mathrm{g}$, phytylmenaquinone $2 \mathrm{mg}$, riboflavin $5 \mathrm{mg}$, pantothenic acid $10 \mathrm{mg}$, nicotinic acid $20 \mathrm{mg}$, cyanocobalamin $12 \mu \mathrm{g}$, iron $100 \mathrm{mg}$, zinc $100 \mathrm{mg}$, manganese $40 \mathrm{mg}$, copper $15 \mathrm{mg}$, iodide $2 \mathrm{mg}$, cobalt $0.5 \mathrm{mg}$, selenium $0.15 \mathrm{mg}$.

$\S$ Pigvite no. 2 plus pyridoxine $20 \mathrm{mg}$, pantothenic acid (additional) $5 \mathrm{mg}$, magnesium $210 \mathrm{mg}$.

\section{Measurements}

On the 1st day of each 2-week period the pigs were weighed and their rations for the period were calculated by adding $3.5 \mathrm{~kg}$ to their weight. On the 6th day bladder catheters were introduced and on the 7th day complete collections of faeces and urine were begun. In each period two successive $24 \mathrm{~h}$ measurements of energy exchange were made in two of the closed-circuit respiration chambers described by Wainman \& Blaxter (1969). The chambers were maintained throughout at $20^{\circ}$ (actual mean $19.6^{\circ}$ ). For two pigs in each four these measurements were on days 11 and 12 and for the other two pigs on days 13 and 14 of each period. $H(\mathrm{~kJ})$ was calculated from oxygen consumption (litres), carbon dioxide production (litres) and urinary $\mathrm{N}$ excretion (g) using the equation of Hoffman (1958) which was designed specifically for pigs, and which, converted to $\mathrm{kJ}$, is:

$$
H=5 \cdot 23 \mathrm{CO}_{2}+16 \cdot 07 \mathrm{O}_{2}-122 \cdot 9 \mathrm{~N} \text {. }
$$

Urine was collected directly into $250 \mathrm{ml} 10 \mathrm{M}$-sulphuric acid; faeces were removed daily and transferred to acid.

\section{Statistical analysis}

Results were analysed using GENSTAT. The weights of the animals at the times of measurement were calculated by linear interpolation between weights taken every 2 weeks. 


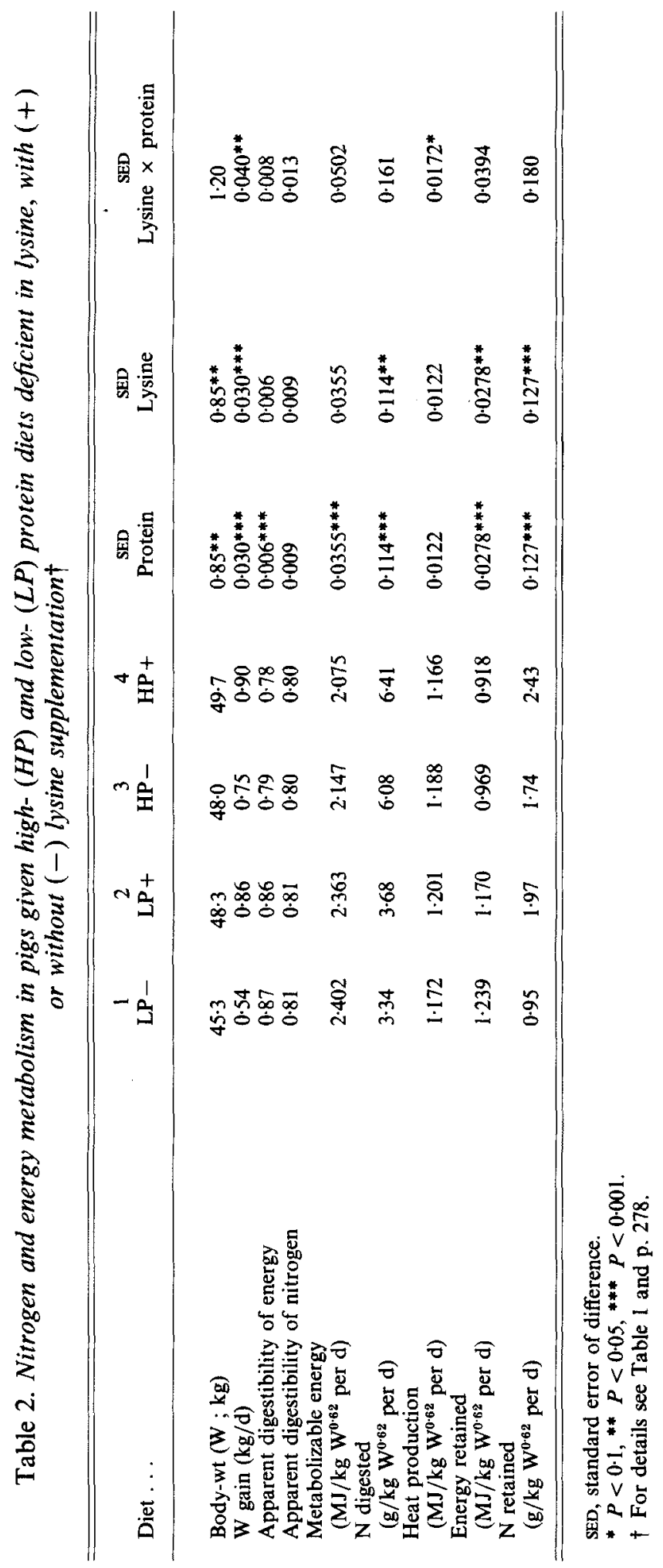




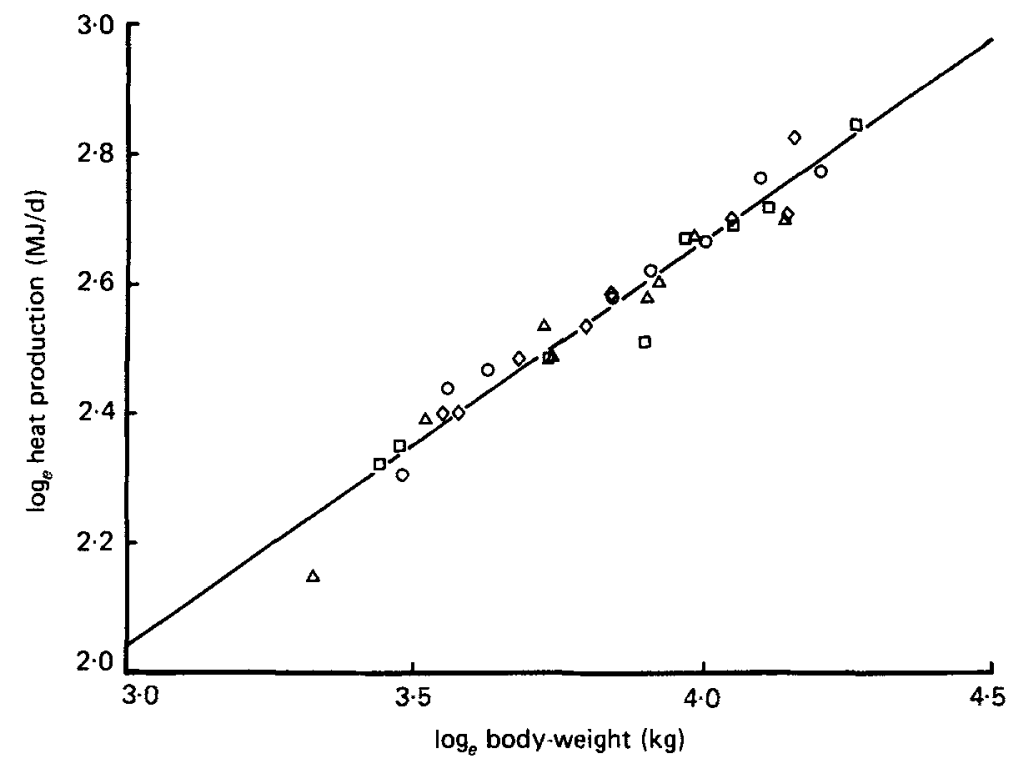

Fig. 1. The relation between $\log _{\mathrm{e}}$ heat production $(H)$ and $\log _{\mathrm{e}}$ body-weight $(W)$. Each point represents the mean of two consecutive $24 \mathrm{~h}$ measurements of the $H$ of the same animal. No adjustment has been made for treatement differences. $(\triangle)$, low-protein (LP) diet without lysine supplementation; $(\diamond)$, LP with lysine supplementation; (O), high-protein (HP) diet without lysine supplementation; ( $\square$ ), HP diet with lysine supplementation. For details of diets, see Table 1 and p. 278. The equation was:

$$
\left.\log _{\mathrm{e}} H=0.172 \text { (SE } 0.0959 \text { ) }+0.623 \text { (SE } 0.0250\right) \log _{\mathrm{e}} \mathrm{W}(r \quad 0.977) \text {. }
$$

\section{RESULTS AND DISCUSSION}

There were no missing observations : all the pigs ate well and there were only three minor food refusals.

\section{Body-weights and weight gain}

The rates of weight gain are given in Table 2 and show the very large effect of lysine supplementation. The slight differences in weights between treatment probably arose because, for the purpose of rationing the animals, the same increase in body-weight from day 1 to the midpoint of the period was assumed, whereas the weight gains were in fact greatly affected by treatment.

\section{Expression of results}

Because of the increase in body-weight during the experiment it was necessary to adjust results in successive periods for differences in body-weight. Examination of the results suggested that linear covariance would be inappropriate and the results were then expressed per $\mathrm{kg} \mathrm{W}^{0.75}$. However, these scaled values also changed significantly with body-weight and accordingly an alternative basis was sought. The overall relation between $H(\mathrm{~kJ} / \mathrm{d})$ and body-weight $(\mathrm{kg})$ (Fig. 1) was described by the equation

$$
H=1188 \mathrm{~W}^{0.62} \text {. }
$$

The correlation coefficient was 0.977 . Although the exponent 0.62 is substantially lower than 0.75 , it accords with exponents found in previous work with growing pigs: 0.57 (Breirem, 1939), 0.57 (Fuller \& Boyne, 1972); 0.55 (Fuller et al. 1980). Analysis of published 
Table 3. Rates of energy retention as protein and as fat and estimates of the heat production which was associated with fat deposition $(13.9 \mathrm{~kJ} / \mathrm{g})$ and that which was not in pigs given high$(H P)$ and low- $(L P)$ protein diets deficient in lysine, with $(+)$ or without $(-)$ lysine supplementation $\dagger$

(All values are expressed as $\mathrm{kJ} / \mathrm{kg}$ body-weight $\mathrm{t}^{0.62}$ per $\mathrm{d}$ )

\begin{tabular}{lrrrr}
\hline & 1 & 2 & 3 & 4 \\
Diet $\ldots$ & LP - & LP + & HP - & HP + \\
\hline Energy retained as protein & 140 & 291 & 257 & 360 \\
Energy retained as fat & 1101 & 881 & 702 & 549 \\
Heat production : & 387 & 310 & 247 & 193 \\
$\quad$ Associated with fat deposition & 785 & 891 & 941 & 973 \\
\hline Not associated with fat deposition & \\
\hline
\end{tabular}

$\uparrow$ For details of diets, see Table 1 and p. 278.

values (Agricultural Research Council, 1981; Brown \& Mount, 1982) strongly supports the contention that, although 0.75 is the appropriate exponent for comparing adults of different species, the appropriate exponent for comparing different sizes of growing pigs is close to $0 \cdot 6$. Accordingly, the results of these experiments have been expressed per $\mathrm{kg}$ $\mathrm{W}^{0.62}$. The residual coefficient of variation of $H$ from analysis of the two Latin squares was 0.027 of which 0.023 was the variation between consecutive $24-\mathrm{h}$ measurements. Individual values for the major variables are given in the Appendix.

\section{$N$ metabolism}

In Table 2 are given the mean values for each diet of $\mathrm{N}$ apparently digested, apparent $\mathrm{N}$ digestibility and $\mathrm{N}$ retention. The $\mathrm{N}$ of all diets was apparently equally well digested, $0 \cdot 80-0.81$, and supplementation with lysine did not alter its digestibility. This is discussed further in the following paper (Fuller et al. 1987b).

The rate of $\mathrm{N}$ retention was significantly increased by the addition of lysine to both the LP and HP diets. The increase was much greater with the LP diet, although the interaction was not significant.

\section{Energy metabolism}

The digestibility of the energy of the LP diets was significantly higher than that of the HP diets. The LP diets included a large proportion of highly digestible carbohydrates. Accordingly, the daily ME was significantly greater for the pigs on the LP diets.

Differences in $H$ with diet were small and there was no significant effect of increasing either protein or lysine concentration. There was a tendency for the addition of lysine to the LP diet to increase $H$, whereas with the HP diet, $H$ tended to be reduced; this interaction was almost significant $(P<0.06)$.

\section{General discussion}

The main question which this experiment sought to answer was how much does $H$ increase with $A$ when there is no change in energy intake? Had addition of lysine provoked no changes other than in $\mathrm{N}$ retention and $H$, it would have been possible to draw some direct inferences about the relation between the two. In fact, when lysine was added to the diets there was not only an increase in $\mathrm{N}$ retention but a concomitant reduction in fat deposition. This can be seen in Table 3, where the energy retention is divided into that retained as protein $(\mathrm{N}$ retention $\times 148.1 \mathrm{~kJ} / \mathrm{g}$ ) and that retained as fat (the remainder). With diet 1 , fat 
accounted for 0.89 of the retained energy, whereas with diet 4 the proportion was only $0 \cdot 60$.

There is a second slight complication, which arises from differences in the composition of the substrates available for ATP and fat formation. It has been calculated (for example, see Schiemann, 1963) that the energy of the carbon skeletons of amino acids are utilized for ATP formation with only 0.85 of the efficiency of carbohydrates. From the urinary $N$ excretion the contribution of amino acids to total $\mathrm{ME}$ (other than that of the protein accreted) can be calculated. For diets $1-4$, this proportion was $0.16,0.12,0.34$ and 0.34 respectively. Compared with all-carbohydrate diets, therefore, the relative efficiency of utilization of the energy in the four diets was calculated to be $0.98,0.98,0.95$ and 0.95 respectively. This means that rather more heat would have been generated in the metabolism (to ATP and fat) of the energy in diets 3 and 4 than in diets 1 and 2.

To calculate the increases in $H$ associated with the increases in $A$, it is necessary to make allowance for the simultaneous change in the rate of fat deposition. The $\mathrm{ME}$ required for the deposition of $1 \mathrm{~g}$ fat from (predominantly) carbohydrate has been estimated in respiration experiments with mature pigs to be $53.5 \mathrm{~kJ}$ (Schiemann et al. 1961). Numerous other estimates have given substantially the same value (for review, see Agricultural Research Council, 1981).

An overall regression was calculated of the $H$ not associated with fat deposition $\left(H_{n} ; \mathrm{kJ} / \mathrm{kg} \mathrm{W}^{0.62}\right.$ per d) on the rate of $A\left(\mathrm{~g} / \mathrm{kg} \mathrm{W}^{0.62}\right.$ per d). This (adjusted for the effects of animals and periods) gave the relation:

$$
H_{n}=668(\mathrm{SE} 33 \cdot 1)+16 \cdot 6 \mathrm{~A}(\mathrm{SE} 2 \cdot 03)(n \text { 32). }
$$

The constant term 668 is an estimate of the $H$ not associated with either fat deposition or $A$. It is rather lower than the energy requirement for maintenance (in the sense of energy equilibrium) of $741 \mathrm{~kJ} / \mathrm{kg} \mathrm{W}^{0.62}$ per d (i.e. the Agricultural Research Council (1981) estimate of $719 \mathrm{~kJ} / \mathrm{kg} \mathrm{W}^{0.63}$ per d converted to the slightly different exponent at the mean body-weight of these pigs). This discrepancy is to be expected as a result of the considerable rate of $\mathbf{N}$ retention associated with energy equilibrium in growing pigs which has been observed in our own (Fuller et al. 1976; Reeds et al. 1980) and others' experiments (Close et al. 1978).

The regression coefficient 16.6 suggests that $H$ was increased by $16.6 \mathrm{~kJ} / \mathrm{g}$ increase in $A$. However, this overall regression is not appropriate because the changes in $H_{n}$ with change in $A$ were quite different according to whether lysine or protein was used to increase $A$. Addition of lysine increased $H_{n}$ by $16.6 \mathrm{~kJ} / \mathrm{g}$ increase in $A$ with the LP diet and by $7.4 \mathrm{~kJ} / \mathrm{g}$ with the HP diet. With addition of protein on the other hand, $H_{n}$ increased by $31.6 \mathrm{~kJ}$ (without lysine) and $28.5 \mathrm{~kJ}$ (with lysine) $/ \mathrm{g}$ increase in $A$. It seems clear that to increase $A$ by giving more dietary protein is energetically more expensive than by improving the quality of the protein. The ratio, $H_{n}: A$ from all the treatments was $19 \cdot 4$, an estimate not significantly different from the value of 20.3 suggested (Fowler et al. 1980; Agricultural Research Council, 1981) as representative of a number of experiments with different protocols which involved changes in energy intake, protein intake or both. The present results suggest that the observed associations do not arise from a general increase in metabolism consequent on the ingestion of increased amounts of energy or protein but are specifically associated with the processes of protein metabolism. Our examination of some of these processes in the same dietary circumstances is described in the following paper (Fuller et al. 1987b).

The authors wish to thank Miss R. A. Fordyce for chemical analysis, Mr J. S. Smith for help with the measurements of energy exchange and Dr A.C. Brewer for statistical analysis. 







\section{REFER ENCES}

Agricultural Research Council (1981). The Nutrient Requirements of Pigs. Slough: Commonwealth Agricultural Bureaux.

Breirem, K. (1939). Tierernährung 11, 487-528.

Brown, D. \& Mount, L. E. (1982). Livestock Production Science 9, 389-398.

Close, W. H., Mount, L. E. \& Brown, D. (1978). British Journal of Nutrition 40, 423-431.

Fowler, V. R., Fuller, M. F., Close, W. H. \& Whittemore, C. T. (1980). In Energy Metabolism, European Association for Animal Production, publication no. 26, pp. 151-156 [L. E. Mount, editor]. London: Butterworths.

Franke, E.-R. \& Weniger, J. H. (1958). Archiv für Tierernährung 8, 81-94.

Fuller, M. F. \& Boyne, A. W. (1972). British Journal of Nutrition 28, 373-384.

Fuller, M. F., Cadenhead, A., Reeds, P. J., Mollison, G. \& Seve, B. (1987a). In Energy Metabolism of Farm Animals, European Association for Animal Production, publication no. 32, pp. 2-5 [P. W. Moe, H. F. Tyrell and P. J. Reynolds, editors] Totowa : Rowman \& Littlefield.

Fuller, M. F., Gordon, J. G. \& Aitken, R. (1980). In Energy Metabolism, European Association for Animal Production, publication no. 26, pp. 169-174 [L. E. Mount, editor]. London: Butterworths.

Fuller, M. F., Reeds, P. J., Cadenhead, A., Seve, B. \& Preston, T. (1987 b). British Journal of Nutrition 58, $287-$ 300.

Fuller, M. F., Webster, A. J. F., MacPherson, R. M. \& Smith, J. S. (1976). In Energy Metabolism of Farm Animals, European Association of Animal Production, publication no. 19, pp. 177-180 [M. Vermorel, editor]. Clermont Ferrand: G. de Bussac.

Hoffman, L. (1958). Wissenschaftliche Abhandlungen, Deutsche Akademie der Landwirtschaftswissenschaften 37, 83-91.

Kielanowski, J. (1965). In Energy Metabolism, pp. 13-19 [K. L. Blaxter, editor]. London: Academic Press.

Kielanowski, J. (1966). Animal Production 8, 121-128.

Millward, D. J., Garlick, P. J. \& Reeds, P. J. (1976). Proceedings of the Nutrition Society 35, 339-349.

Reeds, P. J., Cadenhead, A., Fuller, M. F. \& Lobley, G. E. \& McDonald, J. D. (1980). British Journal of Nutrition 43, 445-455.

Schiemann, R., Hoffman, L. \& Nehring, K. (1961). Archiv für Tierernährung 11, 265-283.

Schiemann, R. (1963). Beiträge zum Eiweissproblem. Sitzungsberichte Deutsche Akademie der Landwirtschaftswissenschaften 12, 39-58.

Wainman, F. W. \& Blaxter, K. L. (1969). In Energy Metabolism of Farm Animals, European Association for Animal Production, publication no. 12, pp. 429-433 [K. L. Blaxter, J. Kielanowski and G. Thorbek, editors]. Newcastel: Oriel Press Ltd.

Waterlow, J. C., Garlick, P. J. \& Millward, D. J. (1978). Protein Turnover in Mammalian Tissues and in the Whole Body. Amsterdam: North Holland. 